\title{
Changing Fortunes or Changing Attitudes: Sentencing and Corrections Reforms in 2003
}

Jon Wool

Don Stemen

Loyola University Chicago, dstemen@luc.edu

Follow this and additional works at: https://ecommons.luc.edu/criminaljustice_facpubs

Part of the Criminology and Criminal Justice Commons

\section{Recommended Citation}

Wool, J and D Stemen. "Changing Fortunes or Changing Attitudes: Sentencing and Corrections Reforms in 2003." Federal Sentencing Reporter 16(4), 2004.

This Article is brought to you for free and open access by the Faculty Publications and Other Works by Department at Loyola eCommons. It has been accepted for inclusion in Criminal Justice \& Criminology: Faculty Publications \& Other Works by an authorized administrator of Loyola eCommons. For more information, please contact ecommons@luc.edu.

\section{(c) $\odot ९$}

This work is licensed under a Creative Commons Attribution-Noncommercial-No Derivative Works 3.0 License. (c) VERA Institute of Justice, 2004. 


\section{Issues in Brief}

\section{Changing Fortunes}

or

\section{Changing Attitudes?}

\section{Sentencing and}

\section{Corrections Reforms}

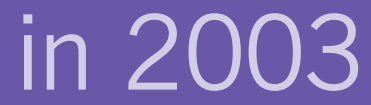

Jon Wool

Don Stemen

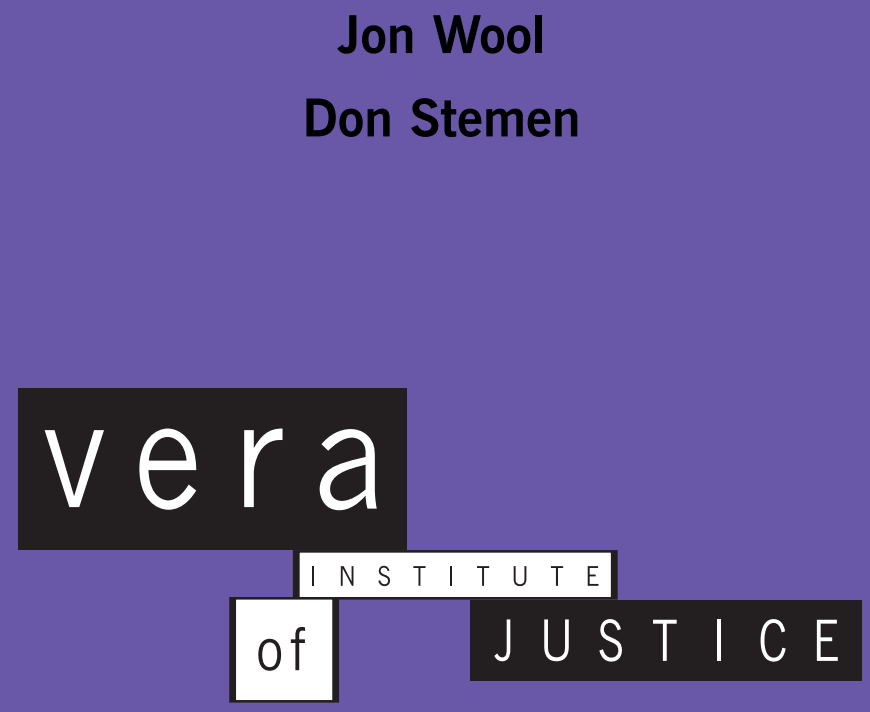

\section{$\infty$ \\ $-1$ \\ D \\ ता \\ A}

o

$\Gamma$

$Z$

$-$

एा

$\frac{2}{z}$

$\Omega$

$I$

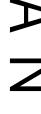

S TAT E LEG I S L A T O R S

and governors begin to address sentencing and corrections policy in the third straight year of severe economic crisis, what can they learn from their colleagues' recent efforts? In addition to continued cutting of administrative costs, more than 25 states took steps to lessen sentences and otherwise modify sentencing and corrections policy during the 2003 legislative sessions. Thirteen states made significant changes, ranging from the repeal or reduction of mandatory minimum sentences for drug-related offenses to the expansion of treatment-centered alternatives to incarceration. These developments suggest that many states have changed the way they look at sentencing and incarceration. ${ }^{\mathrm{I}}$

This Issue in Brief surveys the most recent changes to the states' sentencing and corrections policies to identify the range of reforms being implemented in these persistently tight economic times. It also explores whether there is more to these developments than fiscal belt-tightening. Do changes in law and policy indicate fundamental shifts in attitudes about appropriate responses to various types of offenses and offenders? If so, in what ways?

Although such questions cannot be answered with certainty until more time has passed, this paper examines several recent examples of reforms that suggest that attitudes, and not just fortunes, have changed. The differences are most evident in three areas: a greater use of data to structure sentencing policy, as seen in Alabama's sentencing reforms; a growing concern for proportionality in sentencing, as reflected in Delaware's realigning of mandatory minimum sentences for drug traffickers and some violent offenders; and a renewed focus on rehabilitation, illustrated by Kansas's emphasis on replacing incarceration with substance abuse treatment and Arizona's efforts to build sound transition programming. 
The legislative changes to sentencing and corrections laws discussed in this paper illustrate that in at least some jurisdictions criminal justice policy is no longer the divisive political wedge it once was. Fiscal concerns are providing common groundand a political safe harbor-for officials of all political stripes looking to temper reliance on incarceration.

But, even if the politics are less contentious, a big question lingers: are the changes solely motivated by financial crisis or do they reflect a shift in thinking among policymakers about what constitutes good criminal justice policy? According to this latest installment of Vera's Issues in Brief series, the answer appears to be that minds are changing along with policy.

Whatever one's motivation, engaging in, or even thinking strategically about, reform possibilities is no easy effort. Vera's State Sentencing and Corrections Program (SSC) provides nonpartisan, non-prescriptive assistance to policymakers from all branches of government involved in such tasks. SSC draws on the expertise of a national network of practitioners to provide counsel that is grounded in the substantive and political considerations that inform these processes. To learn more about how SSC has supported officials in some 20 states, contact (212) 376-3073, dwilhelm@vera.org, or visit the program's web site at www.vera.org/ssc.

Daniel F. Wilhelm, Director

State Sentencing and Corrections Program
Before turning to these examples, however, we offer a survey of state actions across the country. The survey begins by examining ongoing efforts to cut or shift correctional costs. It then describes efforts to turn toward more rational, data-driven sentencing structures by empanelling sentencing commissions. It also reviews two sentencing changes that depart from the get-tough philosophy of the last 20 years: an increase in support for early release provisions, including reducing the demands of truth in sentencing, and the development of new approaches to technical violators. The survey concludes by examining two other closely related initiatives: a push to repeal or reduce minimum sentences for nonviolent offenders and efforts to create or expand treatment-based alternatives to incarceration for addicted offenders.

\section{Recent Changes to Sentencing and Corrections Law and Policy}

The states faced an aggregate $\$ 78$ billion deficit for fiscal year 2004, following hard upon a $\$ 75$ billion shortfall for fiscal year 2003. Two-thirds of the states faced 2004 budget gaps amounting to five percent of their general funds; more than one-third faced shortfalls exceeding Io percent. ${ }^{2}$ Some recent signs suggest that an economic rebound may be beginning to reach state treasuries, but there is little evidence that fortunes will improve significantly in the near future; projected deficits for fiscal year 2005 stand at \$39-\$4I billion. ${ }^{3}$

The protracted budget crunch has been particularly difficult for corrections departments. For more than a decade they had become accustomed to uninterrupted budgetary growth-from an aggregate $\$ 7$ billion budgeted in I990 to \$35 billion in I999-mirroring everexpanding prison and jail populations. 4 Table I shows the changes to corrections budgets and the range of costcutting responses in the current and prior fiscal years.

Cutting or Shifting Costs. From the onset of the fiscal crises states have tried to cut corrections costs with varying success. The effort continues. Vera inquiries revealed that at least nine states decreased their actual corrections expenditures in fiscal year 2003, and at least I4 cut their initial corrections appropriations in fiscal year 2004.5 Examples of ways in which corrections departments have cut costs include the elimination of 500 beds in Utah, 146 fewer corrections officer positions in Missouri, and an end to funding for educational programming in Kentucky. Although there were countervailing occurrences-Arkansas, for example, reopened some 
Table 1. Corrections Budget Changes and Cost-Saving Efforts in Fiscal Years 2003 and 2004

\begin{tabular}{|c|c|c|c|c|c|c|c|c|c|}
\hline \multirow[b]{2}{*}{ State } & \multicolumn{3}{|c|}{ Corrections Budget Changes } & \multicolumn{6}{|c|}{ Cost-Saving Efforts } \\
\hline & $\begin{array}{c}\% \text { Change } \\
\text { in Initial } \\
\text { Appropriations } \\
\text { from FY } 02 \text { to FY } 03\end{array}$ & $\begin{array}{l}\text { \% Change } \\
\text { in Actual } \\
\text { Expenditures } \\
\text { from FY } 02 \text { to FY } 03\end{array}$ & $\begin{array}{c}\% \text { Change } \\
\text { in Initial } \\
\text { Appropriations } \\
\text { from FY } 03 \text { to FY } 04\end{array}$ & $\begin{array}{l}\text { Closed } \\
\text { Facilities; } \\
\text { Delayed Openings; } \\
\text { Reduced Beds }\end{array}$ & $\begin{array}{l}\text { Reduced Staff; } \\
\text { Froze Hiring }\end{array}$ & $\begin{array}{l}\text { Renegotiated } \\
\text { Contracts; } \\
\text { Eliminated } \\
\text { Programs }\end{array}$ & $\begin{array}{l}\text { Eliminated } \\
\text { Pay Increases }\end{array}$ & $\begin{array}{c}\text { Delayed } \\
\text { Maintenance }\end{array}$ & $\begin{array}{l}\text { Reduced } \\
\text { Payments to } \\
\text { Private Prisons } \\
\text { Local Jails }\end{array}$ \\
\hline AL & 13.76 & 11.87 & 6.74 & & & & & & \\
\hline AK & 4.40 & NA & -4.20 & & & & & & \\
\hline$A Z$ & -0.21 & 5.37 & 4.41 & & $\bullet$ & - & & & \\
\hline AR & -3.94 & 7.34 & 10.39 & - & - & & - & & \\
\hline CA & NA & NA & 4.49 & $\bullet$ & $\bullet$ & & & & \\
\hline $\mathrm{CO}$ & 2.93 & NA & 3.22 & $\bullet$ & - & & & & \\
\hline CT & 4.25 & 3.39 & 6.13 & & & & & & \\
\hline DE & 3.28 & 3.50 & 1.45 & & $\bullet$ & & - & - & \\
\hline $\mathrm{FL}$ & 1.85 & 2.53 & 6.01 & & $\bullet$ & & & & \\
\hline GA & 1.40 & 1.97 & -1.17 & & & & & & \\
\hline HI & 1.15 & 4.08 & 6.37 & & - & - & - & - & \\
\hline ID & -12.25 & -10.95 & 2.41 & & - & & & & \\
\hline IL & NA & -9.76 & 6.33 & • & $\bullet$ & $\bullet$ & & & \\
\hline IN & 0.55 & 3.44 & 3.53 & $\cdot$ & • & & & & \\
\hline IA & 1.12 & 2.56 & 5.09 & • & $\bullet$ & & & & \\
\hline KS & 0.09 & -0.54 & -0.36 & • & & • & & & \\
\hline KY & -5.98 & -0.45 & 8.16 & & $\bullet$ & & • & & • \\
\hline LA & 5.32 & NA & 1.47 & & & & • & • & • \\
\hline ME & 5.13 & 4.73 & 12.35 & & & & & & \\
\hline MD & 4.24 & NA & -1.50 & & & & & & \\
\hline MA & 17.07 & NA & 4.05 & • & & & & & \\
\hline MI & 0.00 & NA & 2.05 & • & • & • & & & \\
\hline MN & 4.73 & 7.00 & 1.17 & & • & & & & \\
\hline MS & 1.44 & 1.40 & -7.70 & & & & & & \\
\hline MO & 7.11 & 5.91 & 2.53 & & • & & $\bullet$ & & \\
\hline MT & 0.68 & NA & 10.04 & & & & & & \\
\hline NE & 12.05 & 16.41 & 5.79 & • & & & & & \\
\hline NV & 3.44 & 3.36 & 0.85 & & • & & & & \\
\hline NH & 3.98 & 3.50 & 2.49 & & & & & & \\
\hline NJ & -1.45 & 4.25 & 6.40 & & & & & & \\
\hline NM & 4.48 & 4.83 & 4.33 & & $\bullet$ & & • & & \\
\hline NY & 0.43 & 0.31 & -1.05 & • & • & & & & \\
\hline NC & -4.76 & NA & 6.84 & & & & & & \\
\hline ND & -2.30 & NA & 6.36 & & • & & & & • \\
\hline $\mathrm{OH}$ & 2.30 & NA & 3.70 & • & • & & & & \\
\hline OK & 1.20 & -4.51 & -4.81 & • & • & & • & & \\
\hline OR & 8.33 & -8.86 & -10.24 & & & • & & & \\
\hline PA & 10.04 & NA & 2.54 & & & & & & \\
\hline RI & 3.57 & 7.64 & 2.86 & & & & & & \\
\hline SC & -3.65 & 3.79 & -6.11 & • & & • & & & \\
\hline SD & NA & -15.28 & NA & & & & & & \\
\hline TN & 5.03 & NA & -1.95 & & • & & & & • \\
\hline TX & 0.84 & -2.34 & -5.30 & & & & & & \\
\hline UT & -4.00 & -0.70 & -0.21 & • & • & & • & & \\
\hline VT & 3.57 & 5.76 & $-52.12^{*}$ & • & $\bullet$ & & $\bullet$ & & \\
\hline VA & 0.32 & -0.94 & -4.63 & & & & & & \\
\hline WA & 6.66 & 6.66 & -3.67 & & & & & & \\
\hline WV & 16.60 & 16.60 & 1.27 & & & & & & \\
\hline WI & 2.35 & NA & 0.72 & • & • & & & & • \\
\hline WY & -15.70 & NA & 10.88 & & & & & & \\
\hline
\end{tabular}

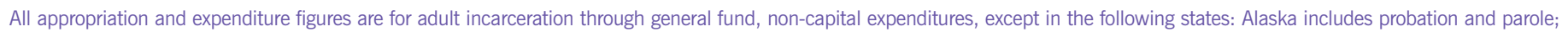

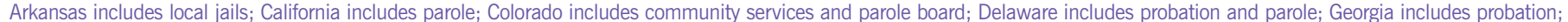
Hawaii includes parole; Illinois includes parole and juvenile; Indiana includes community corrections and juvenile; lowa includes probation and parole; Kentucky includes probation,

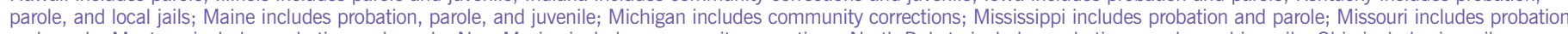
and parole; Montana includes probation and parole; New Mexico includes community corrections; North Dakota includes probation, parole, and juvenile; Ohio includes juvenile; Oklahoma includes probation and parole; Vermont includes probation and parole; West Virginia includes parole; Wisconsin includes probation, parole, and juvenile.

* Vermont's 2004 budget supplements $\$ 50$ million in general fund appropriations with one-time federal funds. 


\section{States that shifted corrections costs}

Alaska (SB 124) reduced its share of support to drug and alcohol treatment centers from 90 percent to 75 percent.

California (AB 1759) imposed a $\$ 20$ court security fee for criminal convictions.

Colorado (SB 177, SB 186) reduced state funds for local community corrections agencies and increased monthly probation supervision fees from $\$ 45$ to $\$ 50$.

Florida (HB 113A) enacted a $\$ 40$ fee to apply for appointed counsel.

Georgia (SB 47) enacted a $\$ 25$ fee for those seeking to transfer parole or probation supervision to another state.

Idaho (HB 50, HB 71) enacted an interstate parole transfer fee of up to $\$ 100$ and increased monthly parole and probation fees from $\$ 35$ to $\$ 40$.

Illinois (SB 1457) enacted an interstate parole transfer fee of up to $\$ 125$ and doubled monthly probation fees to $\$ 50$.

Indiana (SB 205, SB 506) enacted an interstate parole transfer fee of $\$ 75$ and increased monthly probation fees to $\$ 30$ plus a one-time fee of $\$ 100$.

Kansas (HB 2121) doubled its fee to apply for appointed counsel to $\$ 100$.

Louisiana (HB 1732) enacted a $\$ 40$ fee to apply for appointed counsel.

Minnesota (SB 2A) increased its fee to apply for appointed counsel from $\$ 25$ to $\$ 200$.

Mississippi (HB 675) increased monthly parole and probation fees from $\$ 30$ to $\$ 35$.

Montana (HB 222, HB 453) enacted an interstate parole transfer fee of $\$ 50$ and made all inmates responsible for their medical and dental expenses.

Nebraska (LB 46) enacted new $\$ 25$ to $\$ 30$ monthly parole and probation supervision fees plus a one-time probation fee of $\$ 30$.

Nevada (AB 29) increased assessments on all offenders convicted of a misdemeanor. New Mexico (SB 653) raised the daily fee (from $\$ 0.75$ to $\$ 2.00$ ) that privately operated prisons pay to the county that they are located in for each out-of-state inmate.

New York (S 1406-B/A 2106-B) raised the combined conviction fee/surcharge by an average of 32 percent and created a new fee for sex offender registration.

Oklahoma (HB 1484) quadrupled offenders' monthly electronic monitoring fee to $\$ 300$.

Tennessee (SB 1861/HB 1985) increased monthly probation fees from $\$ 35$ to $\$ 45$.

Utah (HB 112) required offenders sentenced to county correctional facilities to pay the costs of their incarceration.

mothballed facilities for use as intermediate sanctions and treatment centers-there was widespread pressure to achieve immediate savings and avoid present and future costs. In two extreme cases-North Carolina and Texas - the mandate to slim down was passed on to inmates through a reduction in the number of meals they were served. 6

States also became more aggressive in 2003 in shifting corrections costs to offenders themselves. Although fees charged to offenders are by no means new-jailer's fees, for example, predate this nationthey emerged as an attractive prospect in I7 states. Illinois doubled its monthly probation supervision fees from \$25 to \$50; Oklahoma quadrupled its electronic monitoring fee to $\$ 300$ a month. However, the newfound popularity of this strategy occasions an unresolved debate about its appropriateness as a correctional tool. While some argue that such fees can help substanceabusing offenders and others to "own" their treatment, opponents contend that they improperly shift costs to those least able to afford them and force probation officers to become debt collectors. ${ }^{7}$ A similar discussion continues over whether such fees are effective as a revenue source. Texas, which has long relied on fees, reported that its probation supervision fees supported one-third of the costs of its county probation departments in fiscal year 200I. ${ }^{8}$ In contrast, Olmsted County, Minnesota, reported that its new mandate to collect county jail fees cost almost twice as much to administer as it took in.?

\section{Empanelling Sentencing} Commissions. Three states established or resurrected sentencing commissions in 2003, while four others created study commissions dedicated to a particular corrections topic. The work of sentencing commissions relies on greater use of data collection and analysis and often results in the promulgation of sentencing guidelines. States taking this route often believe that commissions can improve their analytical capacity to achieve better resource allocation and fairer, more consistent sentencing practices. As scholar Michael Tonry has observed: "Guidelines promulgated by commissions have altered sentencing patterns and practices, have reduced sentencing disparities and gender and race effects, and have shown that sentencing policies can be linked to correctional and other resources, thereby enhancing governmental accountability and protecting the public purse." Io Unlike ad hoc and incremental efforts at legislative or executive decision making in this area, commissions offer a rational and comprehensive approach to policies affecting sentencing. As Tonry says, some commissions "have achieved and maintained specialized 
institutional competence, have to a degree insulated sentencing policy from short-term "crime of the week' political pressures, and have maintained a focus on comprehensive system-wide policymaking." "II

New Mexico is among the jurisdictions moving toward a commission model. It transformed its state criminal justice council into a sentencing commission by granting it new resources and a specific mandate to recommend an overhaul of the state's sentencing system. As part of a long-term initiative to reform its sentencing practices, Nebraska created a Community Corrections Council to develop and ultimately implement statewide enhanced community corrections options, including voluntary sentencing guidelines. The third state, Wisconsin, is in the early stages of formulating a work plan for its new commission.

\section{Expanding Early Release}

Provisions. In 2003 at least I3 states went beyond cutting and shifting costs to change significant aspects of their sentencing and incarceration systems in ways that depart from the get-tough approaches of the last 20 years. At least nine states effectively altered sentences by applying prospective and retroactive increases to existing early release credits. ${ }^{\mathrm{I2}}$ For example, although efforts to reform its stringent drug sentences stalled, New York enacted two earned-release provisions. One grants highest-level drug offenders, who previously were ineligible for any early release credit, twice the merit time available to other inmates. The state estimates that this change will expedite the release of $\mathrm{I}, 300$ offenders in its first year. The second provision creates a mechanism called "presumptive release" that allows those who have adhered to a correctional program plan to be released at their earliest eligibility date without review by the state's parole board.

By focusing on such back-end sentence adjustments rather than outright reductions that are more likely to attract public attention, elected officials may be trying to insulate themselves from charges of being soft on crime. Yet even in some states where truth in sentencing has been explicitly codified, policymakers have expanded early release provisions. Despite protests from some law enforcement officials, Washington increased the amount of

earned-release time available to most drug and property offenders from 33 to 50 percent of their sentences. Iowa took a more direct route, reducing its truth-in-sentencing time-served requirement from 85 to 70 percent. In making such changes, these states appear to be eroding the core principle of truth in sentencing, a historically powerful icon of the tough-on-crime approach.

\section{New Approaches to Technical}

Violators. In another departure from the policies of the last decades, states are rethinking approaches to some violators of probation or

\section{States that expanded emergency and early release mechanisms}

Alabama (HB 3B) authorized four additional "special members" of the parole board with the goal of expediting the release of 5,000 low-level felony offenders.

Arizona (SB 1291) allowed inmates participating in a transition program to be released three months earlier than their prior earliest release date.

Arkansas (SB 720) expanded the Board of Correction's powers to declare an overcrowding emergency and release nonviolent state inmates from prison when the state prison backlog in county jails rises above 500 inmates.

Indiana (SB 482) allowed most offenders to receive additional good time credit for having earned a diploma or degree before July 1,1999 , or for the completion of a literacy and basic life skills program.

lowa (SF 422) decreased the amount of time violent offenders are required to serve from 85 to 70 percent of their sentence.

Missouri (SB 5) allowed earlier parole eligibility for many classes of offenders.

Nebraska (LB 46) eliminated two requirements-that offenders with drug or alcohol convictions serve 12 months before parole eligibility, and that offenders convicted of certain drug offenses complete treatment prior to becoming eligible for parole-and created a legislatively imposed prison cap and an emergency release mechanism for when the prison population exceeds the cap.

Nevada (AB 105) allowed offenders to earn sentence reduction credits while on parole and authorized the Department of Correction to award additional credits to parolees for diligence in labor or study.

New York (S 1406-B/A 2106-B) created a "presumptive release" program that allows offenders who receive an earned eligibility certificate to be released by the Department of Correctional Services without review by the parole board. It also provided A-1 drug offenders with a merit time credit of up to one-third of the minimum term.

Washington (SB 5990) increased the maximum earned-release time available to most drug and property offenders from 33 percent of their sentences to 50 percent.

Wisconsin (SB 44) authorized most inmates to petition the sentencing court for placement in a facility-based drug treatment program, upon completion of which they must be paroled regardless of the length remaining in their sentences. 


\section{States that altered approaches to technical probation and parole violations}

Arkansas (HB 1006A, HB 1024A) committed over the next biennium $\$ 6.6$ million to build and $\$ 12$ million to operate a technical violator center.

Colorado (SB 252) allowed the Parole Board to revoke nonviolent violators to a community corrections program or a pre-parole release and revocation center and limited to 180 days the time a nonviolent parolee can be revoked to prison or to an alternative.

Delaware (SB 50) reduced probationary sentences to between one and two years for nonviolent offenders.

Nebraska (LB 46) provided probation officers the authority to impose administrative sanctions in lieu of revocations for technical probation violations.

Nevada (SB 232) provided the parole board with discretion to impose shorter terms of re-incarceration for, and to restore earned release credits to, technical violators whose mandatory-release parole is revoked.

Washington (SB 5990) ended active supervision for many low-level felony postreleasees.

parole. National statistics indicate that a substantial number of those admitted to prison each year are probation or parole violators.

Research in the states suggests that most of these men and women are imprisoned for technical violations, generally defined as those in which the violator has no new criminal conviction. 13 The Bureau of Justice Statistics reports that 36 percent of state prison admissions in $200 \mathrm{I}$, or some 2I5,000 offenders, were parole violators who did not have a new court commitment. ${ }^{4} 4$ In Kansas, for example, 65 percent of prison admissions in fiscal year 2003 were probation and parole/post-release violators sentenced for reasons other than a new conviction. ${ }^{5}$ As they begin to recognize the costs associated with these numbers, state policymakers are altering statutes and regulations to limit incarceration of technical violators.

A legacy of exceptionally long probation terms in Delaware left the state with 3.4 percent of its adult population under supervision-the second highest rate in the nation, behind Washington (and tied with Texas). ${ }^{16}$ As a consequence, viola- tions, including technical violations, make up 40 percent of jail and prison admissions. ${ }^{\mathrm{I}}$ To reduce this rate, Delaware's legislature cut probation terms to a maximum of two years for all but sex and violent offenders and provided for administrative, non-prison resolution of technical violations. Washington sought to reduce the number of its technical violators by ending supervision of those who are released after serving sentences for low-level felonies, not including those whose release is conditioned on participation in treatment. Another state with a large population of technical violators, Colorado, simply limited the incarceration period for technical violations of parole to I8o days and authorized commitment to a revocation center instead of prison. ${ }^{18}$

\section{Rethinking Minimum Sentences for Nonviolent Offenders. Before the fiscal crises, legislators focused almost exclusively on increasing sentence lengths in response to perceived public pressure. Policy- makers now appear to be comfort- able exploring reductions in prison}

sentences, too- at least for nonviolent offenders. It is not clear how much of this shift is an effort to weather tough fiscal times before returning to the policies of old, but some legislators appear to have become convinced that, money aside, sentencing policy should change. Notably, a central tenet of the tough-on-crime approach, mandatory minimum sentencing, is on the table.

Five states reduced sentences for nonviolent offenders in 2003. Michigan took a broad approach in the last days of 2002, reducing mandatory minimum sentences across the board for drug offenses. The effort gained national attention because it repealed some of the country's most stringent drug sentences. ${ }^{19}$ Delaware reduced mandatory minimum sentences more incrementally by focusing on making drug sentences less severe in proportion to sentences for violent offenses (see page Io). Two other noteworthy initiatives, in Colorado and Washington, linked sentence reductions to increases in rehabilitative programming. In both states, savings resulting from giving substance-abusing offenders shorter sentences are channeled to provide those offenders with facility- and community-based treatment.

On the other hand, at least six other states-Louisiana, Maryland, Montana, New Hampshire, New York, and North Carolina-considered, but did not enact, legislation to reduce sentences for particular categories of offenders. The reasons behind these decisions vary, but four concerns are commonly voiced: that the public will view reducing minimum sentences as soft on crime, which remains a political liability; that alternatives to incarceration are either ineffective or serve insufficiently to punish offenders; 
that, public perceptions aside, crime may increase if prison sentences are decreased; and that the promised cost savings from reducing sentences are either illusory or will only be realized too far in the future. In Maryland, for example, a bill to eliminate mandatory minimum sentences for repeat drug offenders did not emerge from the House judiciary committee.

According to one of its co-sponsors, Delegate Anthony Brown, "Maryland has difficulty making reforms when it comes to how severely we sentence our offenders. We punish people." ${ }^{20}$ With respect to the drug offender sentencing bill in particular, Brown points to "a sentiment among some members that drug offenders are violent criminals, that to call them nonviolent is inaccurate," as well as the persistent reluctance to vote for measures that might earn them the soft-on-crime label.

\section{Expanding Treatment-Based}

Alternatives to Incarceration.

In some states, however, there is an emerging consensus that sentences for drug offenses, particularly lowlevel possession offenses, should be revisited, and that treatment alternatives may not only be more cost effective but also more appropriate than prison. Senator Kermit Brashear of Nebraska is part of this consensus. "Oftentimes you put a nonviolent substance abuser in prison and a violent substance abuser will come out," he explains. "[N]onviolent offenders and substance abusers...should be provided rehabilitation instead of simply throwing them away in prison." ${ }^{21}$

This is not to deny that many forms of substance abuse treatment programming have been cut along with corrections and other agency budgets. In 2003 Pennsylvania cut roughly 20 percent of its community-based treatment dollars for both offenders and the general public. Alaska made significant reductions to facility-based treatment programs. In general, programs that promise near-term savings-such as those that offer diversion from prisonare garnering support, while those that do not-such as facility-based treatment-are suffering cuts.

Even more telling, however, are recent initiatives that buck this trend by investing in treatment without the promise of a near-term fiscal payback. In Maryland, despite the legislature's decision not to enact drug sentencing reform, Mary Ann Saar, the secretary of public safety and correctional services, has proposed a significant re-direction of correctional resources toward rehabilitation for substance-abusing offenders. Among other things, the proposal would replace corrections officer positions with teachers and counselors. Saar is also calling for a more than four-fold increase in prison treatment beds and a large boost in educational programming. The goal of these proposals, according to Governor Robert Ehrlich, is to stop "the revolving door that keeps inmates coming back into the system, when they should return home with the treatment services necessary to become productive members of society." 22

It is too early to tell whether the proposal will translate into concrete and amply funded facility-based treatment programs, but the past year's legislative activity across the nation reveals that Maryland is part of a larger sentencing trend. Five states enacted often complex and long-planned sentencing reforms that replace jail and prison sentences with substance abuse treatment programming. These reforms include Kansas's mandatory diversion bill (see page II) and Indiana's discretionary Forensic Diversion Program, which authorizes judges to divert all offenders for whom substance abuse or mental illness was a contributing factor in the offense. 23 Other states have carved out new funding to support drug courts, too. California, for example, transferred an additional \$2.I million from the corrections budget to support drug courts that divert otherwise prison-bound offenders. With a similar diversion proviso, Michigan appropriated an additional \$I.3 million annually to support its drug courts.

\section{States that repealed mandatory minimums and otherwise reduced sentences}

Colorado (SB 318) reduced penalties for possession of one gram or less of any controlled substance and allowed judges to sentence to community supervision rather than to prison.

Delaware (HB 210) decreased mandatory minimum sentences for trafficking in illegal drugs. The bill also increased sentences for six violent offenses.

Maine (LD 856) lowered the available mandatory minimum sentence for anyone convicted of trafficking drugs to a minor. Previously, only those with no prior criminal histories might be sentenced to these lower minimums.

Michigan (Public Acts 665, 666, and 670) eliminated most of Michigan's mandatory minimum sentences for drug offenses and provided for shorter probation terms.

Washington (SB 5990) accelerated the implementation of the Drug Sentence Reform Act of 2002, which instituted a new drug offense grid that significantly reduces sentences for all drug offenses. 


\section{Changing Attitudes: Four Case Studies}

Conversations with policymakers in the second half of 2003 indicate that public and political attitudes toward some aspects of criminal sentencing are changing. In fact, the shift began before the onset of the budget crises, resulting in part from steadily decreasing violent crime rates and a growing concern in some quarters about the numbers and racial and ethnic make-up of people sent to prison. 24 Of course, such changes do not lead inevitably to changes in policy. Indeed, perhaps a dozen legislative initiatives to shift correctional priorities were offered but not enacted in the past I 8 months. These include attempts to mandate diversion for drug possession offenses in Louisiana, Massachusetts, and Montana, and efforts to authorize departures from

\section{States that mandated drug treatment and fostered other alternatives to incarceration}

Alabama (SB 337) authorized a county commission to establish a locally run community punishment program and authorized judges to sentence offenders to such programs in lieu of incarceration. The bill also established the Community Corrections Division in the Department of Corrections to assist counties in establishing and maintaining community-based punishment programs.

Arkansas (HB 2353) established a statewide system of drug courts and increased funding by almost $\$ 3$ million for fiscal year 2004 to expand the number of drug courts in the state from seven to 27 .

California increased funding for its drug courts by approximately $\$ 2.1$ million in fiscal year 2004; the funds are to be transferred from the corrections budget and are to target otherwise prison-bound offenders.

Colorado (SB 318) authorized judges to sentence those convicted of possessing one gram or less of any controlled substance to community supervision rather than to prison and provided for at least $\$ 2.2$ million per biennium for treatment services.

Idaho (HB 369) provided for a two percent surcharge on liquor sales and earmarked the funds for drug courts.

Indiana (HB 1001) gave judges discretion to suspend the entire sentences of offenders convicted of any crime when drug or alcohol use or mental illness is a contributing factor. Offenders are put on probation and diverted to a community treatment program.

Kansas (SB 123) mandated drug treatment for possession offenders who have no felony convictions for person crimes or for drug trafficking. The Sentencing Commission estimates that the total population for treatment will be 1,439 offenders per year. Technical violations alone will not result in discharge from the program or revocation to prison; rather, such offenders may be subject to an array of non-prison sanctions.

Louisiana (SB 108) authorized judicial districts to establish job intervention programs for certain nonviolent first-time offenders in lieu of incarceration.

Michigan (SB 281) increased state funding by $\$ 1.3$ million and federal Byrne funding by $\$ 1.8$ million to support drug court programs that target prison-bound offenders.

Missouri (SB 5) allowed courts to sentence nonviolent offenders to 12 to 24 months of a drug abuse treatment program in lieu of incarceration.

Texas (HB 2668) required a probationary sentence for first time drug possessors convicted of possessing amounts of controlled substances that are punishable as state jail felonies. For drug possessors with prior felony convictions, judges have discretion to impose a probationary sentence with treatment. The bill is estimated to lower the state jail population by 2,500 people and save the state $\$ 30$ million over the next five years.

mandatory minimum sentences in Maine. Still, efforts at change are widespread, gaining sturdier political legs, and continuing to grow both in number and kind.

To better understand the vitality of these developments, one must look beyond the product to the process and how policymakers describe their goals and the nature of the debate. The following case studies examine how policymakers in four states describe the changing attitudes that led to reform. In each case one can begin to discern a sea change from the policies of the past 20 years, even if it remains to be seen how deep and sustainable these shifts are.

\section{Alabama}

Using Data to Craft Reforms. With a rate of incarceration 43 percent greater than the national average, Alabama puts more people in prison relative to its population than all but four other states. ${ }^{25}$ However, it is also one of the poorest states in the nation and hard pressed to pay for such toughness-a problem recently underscored when voters rejected a tax hike championed by the new Republican administration that would have financed increases in corrections spending. As a result, Alabama spends less per inmate than any other state-about $\$ 10,000$ per year. It is also subject to two court orders to relieve its overcrowded prisons and faces additional pending litigation alleging inadequate health care for inmates. With 28,000 inmates housed in prisons built for 12,000 and no new tax support on the horizon, the state is now creating a special parole docket to accelerate the release of 5,000 nonviolent inmates. The need for sentencing change is clear.

Fortunately, the state's efforts to apply a rational approach to sentencing have begun to bear fruit thanks 
to careful data collection and analysis provided by the Alabama Sentencing Commission. From its inception in 2000 , the commission focused on establishing a comprehensive database of offender and incident demographics as well as models it can apply to provide analyses and projections. Its commitment to data collection and analysis prompted the legislature to hold off on changes that affect sentences until the commission could make its recommendations. “They didn't drop criminal law bills in the hopper like they used to; they wanted to know what a bill's impact would be on the prison population based on our felony offender data," explains Lynda Flynt, the commission's executive director. ${ }^{26}$ The commission also had the support of Alabama's then-attorney general, Bill Pryor, a proponent of data-driven reform.

In 2003 the commission proposed a trio of sentencing changes. The proposals, which included a long-term sentencing reform act requiring the development of a datadriven structured sentencing system, were grounded in analyses of data from 64,000 felony cases from the past four years, as well as information from corrections, parole, and other sources.

The commission's shorter-term recommendations included a proposed realigning and raising of felony theft thresholds. For years it had been evident that the classification of theft and related offenses was inconsistent-receiving stolen property of a certain value was a felony, for example, while stealing the same property was a misdemeanor. Although few thought the problem important enough to focus on, the commission's data crunching showed that first- and second-degree theft and related offenses accounted for II percent of Alabama's prison population. 27 Its subsequent analysis of national data showed that the threshold for felony theft was lower in Alabama than it was in 82 percent of the states, and the levels in Alabama were either the same asor lower than-they were in I978.

More importantly, the commission's simulation model provided policymakers with detailed projections of the effects of the proposed statutory changes. Raising the misdemeanor/felony thresholds from \$100 and \$250 to \$500 across the board, with similar increases to the thresholds between felonies of different degrees, would result in 3,000 fewer offenders imprisoned over five years-a nine-percent drop.
The decrease in the female prison population would be an even greater I2 percent. Together, the changes would yield a six-percent drop in the proportion of imprisoned offenders classified as low-security risk, effectively reserving more prison space for high risk, generally violent, offenders.

"We were able to provide an analysis that showed the definite projected impact of very specific changes to the law. That's the first time that's been done in Alabama," recalls Rosa Davis, chief assistant attorney general and a member of the commission's executive committee. "For those who were willing to listen, that impressed them." 28 Apparently enough were willing,

\section{States that established study commissions and sentencing commissions}

Arizona (SB 1387) established a sentencing commission with the broad mandate to investigate and report on a variety of sentencing practices.

Indiana (HB 1145) established a two-year study committee to evaluate sentencing laws and policies.

Maine (LD 1614) created the Commission to Improve the Sentencing, Supervision, Management, and Incarceration of Prisoners. Its mandate is to make recommendations to reduce prison and jail populations (including by identifying appropriate alternatives to incarceration); to reduce corrections costs and recidivism; and to improve public safety.

Nebraska (LB 46) created, as part of a broader sentencing initiative, a Community Corrections Council to develop and implement statewide enhanced community corrections options and begin development of voluntary sentencing guidelines.

Nevada (SCR 38) directed the Legislative Commission to conduct an interim study of halfway houses and other transitional housing for offenders.

New Hampshire (HB 825) established a committee to study methods of safely reducing the prison population.

New Mexico (HB 510) created the New Mexico Sentencing Commission, which it assigned all the tasks and duties formerly undertaken by the Criminal and Juvenile Justice Coordinating Council.

North Dakota (HCR 3008) directed the Legislative Council to study various aspects of the state's criminal justice system.

South Carolina (SB 626) established a joint corrections and penology study committee to study prison population management.

Wisconsin (2002 AB 1; 2003 SB 44) established its Sentencing Commission pursuant to legislation enacted in 2002.

Wyoming (SB 16) directed the Department of Administration and Information to conduct an evaluation and programmatic critique of the state's corrections system. 


\section{"We were able to provide an analysis that showed the definite projected impact of very specific changes to the law. That's the first time that's been done in Alabama."}

because the commission's recommendations were enacted.

For Davis, the legislative success demonstrated that data can be used effectively. In this case, she says, data served an important policy goal. "I think there is a growing change in attitude about who goes to prison. Prison may not be the best form of punishment for some categories of offenders, specifically low-level property offenders." Commission director Lynda Flynt focuses on the difference the capacity for data analysis has made. "Now, every time a sentencing bill comes up in the legislature, they turn to us and ask what effect it is going to have on prison populations. This is groundbreaking for Alabama," she says. Although much work remains for the commission, and the funding challenge continues to be daunting, Davis and Flynt agree that Alabama is closer than ever to achieving a more rational and fair sentencing system.

\section{Delaware}

\section{Proportioning Drug and Violent} Crime Sentences. A growing prison population in Delaware presented policymakers there with a stark choice: either build I, ooo more prison beds or alter sentencing practices. Officials chose the latter option on the theory that an adequate supply of prison beds should be reserved for violent offenders. To make this work in tough fiscal times, they resolved that certain nonviolent offenders must serve less time behind bars. by applying the principle of proportionality, specifically by evaluating sentences for drug and violent offenses in relation to each other.

Because Delaware does not imprison those who possess small quantities of drugs - the population seen as most amenable to non-prison sanctions-or even sellers of small quantities, it had to find its savings among more serious offenders. House Bill 2ro reduced the mandatory minimum sentences for drug traffickers-those who sell or possess quantities indicative of fairly significant selling-and doubled the quantity threshold - to Io gramsfor cocaine and some other drugs to more accurately reflect the crime of trafficking. It also made traffickers eligible to spend the final I8o days of their prison sentences in community corrections facilities or programs, where treatment would be available. For second-offense selling or possessing with intent to sell smaller quantities of most narcotic drugs, the bill eliminated a I5-year minimum prison term and otherwise reduced by half the mandatory minimum sentence. The bill balanced these reductions by increasing the severity level or raising the mandatory minimum sentence for six violent offenses and reclassifying another offense as violent.

Very few states have tried to reform sentencing for people who sell drugs or possess quantities that suggest an intent to sell, let alone people who traffic in more significant quantities. ${ }^{29}$ After all, support for rehabilitative responses to drug addiction may have grown, but sympathy for, or understanding of, "drug dealers" has not. Nonetheless, in Delaware advocacy groups and some members of the legislature were able to make the case that most people who sell or possess these quantities of drugs do so only because they, too, are addicts.

About the time that policymakers were rethinking these sentences, the public was calling for stronger measures against violent felonies, particularly domestic burglaries and firearms offenses. In response to these concerns, Attorney General Jane Brady proposed increasing sentences for firearms and some other violent offenses. Her proposal also would have given judges discretion to depart from mandatory minimum sentences for traffickers of io grams or less of drugs if they had no prior violent felony convictions. But key members of the legislature resisted the change, fearing it would accelerate prison population growth and require the construction of additional beds.

The attorney general and her legislative supporters faced another significant obstacle. A sentencing reform advocacy group with a strong public and legislative following, Stand Up for what is Right and Just (SURJ), had two proposals of its own on the table. One that had garnered the sponsorship of 34 of the state's 62 legislators would have granted judges discretion to depart from any mandatory minimum drug sentence. Still, opposition from the attorney general and key legislators might 
have blocked the proposal's passage. SURJ and other drug reform proponents needed to win over the attorney general, and the attorney general needed to appease legislators' fiscal and drug policy concerns. The table was set for compromise.

Delaware's Sentencing Accountability Commission (SENTAC), which had played an active role in focusing the debate, brokered the compromise. "The two philosophical bents ran into each other. The way it came out is a testament to a new time," says Judge Richard Gebelein, who was then chairman of SENTAC. ${ }^{\circ \circ}$ Steven Wood, chief prosecutor in the attorney general's office, agrees. "What appeared to be an unholy alliance of conservatives and liberals became a cooperative effort to reserve scarce prison beds for violent offenders," he says.3r "SURJ was proceeding from the premise that drug sentences were entirely too harsh; we agreed, to the extent that we saw them as too harsh when compared to sentences for violent offenders." The two sides came together, then, by focusing on how sentences for drug offenders stack up against those for violent offenders, rather than on whether each sentence is appropriate in the abstract.

Among the substantive changes wrought by the bill, the most important to Judge Gebelein is the authority granted to the corrections department to move trafficking offenders from prison to community-based treatment programs during the final i8o days of their sentences. Now, a person convicted of selling or possessing between to and 50 grams of cocaine might serve no more than one and one-half years in prison before being provided with six months of treatment in a halfway house or residential treatment facility. Under the previous law, sale or possession of as little as five grams would have required twice the minimum prison sentence with no provision for community-based treatment after incarceration.

For Judge Gebelein, the legislation is symbolically significant for what it portends. "For I5 years this three-year mandatory minimum [for first felony trafficking] was a line drawn in cement. What was once cast in stone is now negotiable," he says. Gebelein believes the compromise also reveals something important about current attitudes: “There is a greater realization that the people who commit these offenses are addicts, and that addicts might be our friends, neighbors, or associates. Many folks who communicate with their legislators were saying, in effect, 'my son has a drug problem and he doesn't need to be in prison.' Treatment began to be seen as a preferred option."

The fiscal crisis provided only a mid-course assist to Delaware's reform process; change was in the offing well before the crisis took hold. "We and many others have been waging this war for years," explains Victor Battaglia, Sr., an attorney who serves on SURJ's board of directors. ${ }^{32}$ Money played a role in getting the bill passed, Battaglia concedes, but it was not a major factor. "We insisted the debate should not be on how cheaply we can get by but on how we can improve public safety through better drug policies," he says.

Deputy Attorney General Wood has a similar impression: "The financial pressures cause you to look more closely at how you spend your money, but this [bill] was also the product of a more moderate approach. It was assumed that we weren't going to increase capacity at this time, so we focused on a more rational allocation of prison beds."

Indeed, the legislation reflects a reversal in public and legislative perception from the late-I980s, when drug sentences stood unchanged while all others were reduced by twothirds to account for Delaware's truth-in-sentencing legislation. Achieved through consensus grounded in proportionality, it gave broader relief from strict drug sentences than SURJ's proposal would have, and it increased minimum sentences for a greater number of violent offenses than the attorney general's proposal would have, at least as measured in bed savings.

\section{Kansas}

Focusing on Rehabilitation Through Diversion to Treatment. Historically, Kansas has been tough on crime. It requires offenders to serve 85 percent of prison sentences without discretionary parole release and traditionally has sent certain drug offenders, even many who possess small quantities, to prison. Yet Kansas began looking for ways to curb its prison population before the onset of its budget crisis. By 


\section{"It became about what was right, not just about how to save money." -John Vratil, Kansas State Senator}

statutory mandate, the Kansas Sentencing Commission must explore alternatives to incarceration whenever population projections show that capacity will be exceeded within three years-and in the summer of 2000 , the state's prison population was at 98 percent of capacity and growing.

According to Barbara Tombs, the commission's executive director at the time, the commission began focusing on offenders it deemed least likely to cause a public safety concern if diverted from prison: those who possess relatively small quantities of drugs. The trend had been toward incarceration; from I997 to I999, the number of offenders sentenced to prison for first-offense, low-level possession had increased by 65 percent, from 324 to 534 , while the number sentenced to probation had remained steady at just below 900 . Moreover, most people recently sent to prison for first- and secondoffense possession originally were sentenced to probation but were remanded for violating their conditions, a trend that underscored the need for adequate and effective treatment services. Despite the passage in 2000 of Senate Bill 323, instituting mandatory graduated sanctions for probation violators and modified probation and post-release supervision for certain nonviolent offenders, the state was facing a projected prison population increase of almost seven percent by 2003 .

In a heated political landscapeSB 323 had become a central issue in the Republican primary for attorney general after a man who was reported (erroneously) to have been released under the bill was charged with murder-the commission began what Tombs describes as a careful process of examination and analysis, first within the commission and subsequently with the legislature. "The [commission] members came to realize that the current situation was simply recycling offenders and not addressing the root causes of their criminal conduct-addiction," Tombs recalls. 33 At the same time, they recognized that many in the legislature doubted the efficacy of treatment. So they began to learn as much as possible about what other states had done to replace prison with effective treatment alternatives. "We brought in people from California and from Washington and from NCSL [the National Conference of State Legislatures] to report on what works," says Tombs. It was during this process that the budget crisis hit.

In late $200 \mathrm{I}$ the commission decided to propose legislation that would both divert nonviolent drug possessors from prison and institute a comprehensive regimen of effective treatment options-with eligibility narrowly defined to maximize political support and minimize the risk to public safety. It was now time to take the classroom to the legislature. Before long, says Tombs, there was an incipient consensus that prison had not been an effective answer to drug possession, and more and more legislators began asking, "Why build another prison when it's not working?" As debate in committees proceeded, lawmakers overcame their resist- ance to rehabilitative approaches and began exploring broader goals than bed savings. According to Tombs, many were won over by emerging testimony about California's Proposition 36-a fully funded diversion-to-treatment approach. Treatment providers also argued persuasively that a long-term continuum of services could promise far greater recidivism prevention than could prison with only limited treatment-even for the growing number of people who abuse methamphetamine. Tombs credits as well a frank discussion of "the many unspoken costs involved with addiction and incarceration," such as unpaid child support, additional medical costs, and tax revenues lost from people not working.

After two months of debate in the spring of 2003 , the legislature enacted Senate Bill I23, mandating drug treatment and supervision rather than incarceration for lowlevel first- and second-offense drug possession. An estimated I,439 people will be directed to community-based treatment each year as a result, roughly 475 of whom would have gone to prison absent the new legislation. To ensure that participants receive appropriate treatment, the bill called for a twopronged assessment of safety risk and substance abuse needs and stipulated that treatment providers be trained and certified by the Department of Corrections. The legislature underscored its determination to provide rehabilitationand not just free up prison beds-by appropriating $\$ 5.7$ million to fully underwrite the I8-month 
treatment regimen called for in the bill. And the funding-approximately $\$ 4,700$ for each participant-travels with the offender from provider to provider, through detoxification, rehabilitation, relapse prevention, etc.

The state's budget crisis may have been a key catalyst for this legislation, particularly for fiscal conservatives determined to curb prison costs and avoid new prison construction. But some participants in the process offer additional explanations for how tough-oncrime Kansas came to enact a fully funded mandatory treatment diversion bill in the midst of a serious budget crisis and over the opposition of the attorney general and the state's sheriffs, peace officers, and court services officers.

According to Tombs, it was the deliberative process, backed by data and tempered by compromise, that led many to see that rehabilitative approaches to substance-abusing offenders can work and that it was time to reconsider the state's longstanding reliance on prison. A fundamental change in attitude developed in the process of studying the problem and crafting the reform. "The process was about the legislators rethinking and being accountable for what legislatively had been done in the past," she says. In the 2003 session, the legislature did not pass any bills that would have increased the use of incarceration, including one championed by both the governor and the attorney general. Senator John Vratil, chairman of the judiciary committee, says the process convinced many of his colleagues that a rehabilitative alternative to incarceration was not only fiscally wise but also, more importantly, that it was the appropriate criminal justice response for this group of substance-abusing offenders: "It became about what was right, not just about how to save money." 34

\section{Arizona}

Focusing on Rehabilitation Through Transition Services. Debates about correctional responses to drug addiction are not new to Arizona. In I996 6 its voters passed Proposition 200 , the nation's first successful effort to replace incarceration with treatment for some substance abusing offenders. Opponents of the measure have been battling to curtail it and subsequent reform efforts ever since-even as Arizona incarcerates offenders at a greater rate than any of the other I2 western states.35 With its own prisons filled to capacity, Arizona now sends six percent of its inmates to private facilities-both in and out of the state. Yet the debate about the prison population rages on, to the point of becoming the focus of a special legislative session in the fall of 2003. Emerging from this turbulent backdrop, however, are signs of a new attitude toward helping offenders prepare for their return to the community. ${ }^{6}$

Arizona's Senate Bill I29I created a transition program offering drug offenders treatment prior to release from prison and a range of services-job training and employment, housing and health insurance assistance, mentoring,

\section{States that expanded transition programs}

Arizona (SB 1291) created a transition program for drug offenders that provides rehabilitative and training services prior to and after release and allows participants to be released three months earlier than their prior earliest release date. The program will be funded by reinvesting the savings derived from the early releases, as well as by deductions of eight percent from wages earned by drug offenders while incarcerated.

Delaware (HB 210) authorized the release of drug offenders to community-based, treatment-centered programming for the last 180 days of incarceration, and the housing of DUI offenders in such programs for all of their sentences.

Idaho (HB 464) committed $\$ 736,000$ in new general funds to expand transition services.

Missouri (SB 5) allowed nonviolent offenders with two years or less remaining on their sentences to apply for home detention.

Nevada (SB 264) authorized the Department of Corrections to establish locally based reentry programs. Among those eligible are certain prisoners within two years of release, parolees as a condition of parole, and technical parole violators in lieu of revocation of parole.

Oklahoma (HB 1061) required that all nonviolent offenders be moved to work release programs, work centers, community corrections centers, intermediate sanctions facilities, accredited halfway houses, or transitional living centers 210 days prior to release from prison; offenders convicted of violent offenses may be moved to such programs 180 days prior to release.

Virginia (HB 2245) authorized giving nonviolent inmates the opportunity to participate in a residential community program, work release, or other community-based programs within six months of their release date.

Washington (SB 5990) committed \$3 million over two years to pre-release treatment programming.

Wyoming (SB 17) allowed offenders who are within 24 months of parole eligibility to be transferred to a community corrections program. 
and continuing treatment-after they return to the community. Senator Mark Anderson, author of the initiative, says he framed the legislation from the taxpayers' point of view. "We are making a bad investment if we release people from prison no better off than when they went in," he says. "Giving people $\$ 50$ and dropping them off at a homeless shelter after years in prison has meant that we release people whose chances of succeeding are pretty slim."37

The bill established a pilot program that will serve an estimated 200 offenders per year. Approximately $\$ 4,500$ will be made available for services provided to each participant. The legislation focused on people leaving prison with addiction problems because, as Anderson puts it, “you can't be a good employee if you're an addict; you can't be a good parent if you're an addict. It's fundamental to the success of thousands of inmates who are released every year."

But how does Anderson explain the new willingness among legislators to support initiatives that improve offenders' chances? "It's a combination of things," he says. “The big factor is that people's eyes have been opened because so many more are coming out of prison now than any time in the past-because we began locking up so many more people io years ago." It may also be fiscal: "Legislators who would normally have said 'No, I'm tough on crime,' when we asked for their support are now seeing the bill come due from our past policies. So they are ready to support this." Anderson believes legislators are taking courage from a change in the public's view as well. "They [the public] are more sympathetic to the whole issue; they want to see people coming out with a different attitude, with a job, going back to their families. And they too, as taxpayers, see the cost of locking people up."

The bill's most innovative aspect is a funding mechanism that created a self-sustaining link between providing enhanced rehabilitative services and a reduced emphasis on incarceration. The bill directed that participants in the program be released three months earlier than their previous earliest release date, after completing in-facility programming and treatment. The money saved is to be earmarked for preand post-release transition programming. The cost reductions are to be identified by the department, but no less than $\$ 500,000$ must be committed to transition services in fiscal year 2004. By linking the anticipated savings from a reduced emphasis on incarceration to the funding of alternative programming that supports or supplants the reduced incarceration, policymakers are trying to elevate the programming from the realm of "nonessential" correctional services and make it a priority among core corrections goals.

During earlier decades of rapid prison population growth, transition programming received little emphasis and few resources. The success of SB I29I shows a changed attitude toward the possibilities of rehabilitative, educational, and vocational approaches, and the appropriateness of these approaches in the corrections scheme. For Senator Anderson, who included a reporting requirement in the legislation, the bill is important not only for its modest immediate goal but also for what it may lead to. "If this [initiative] helps with recidivism we can expand it. We are trying to build comfort with this and similar ideas; we are trying to build a model."

\section{Conclusion}

In reviewing how states have responded to their budget crises, this Issue in Brief focuses on distinctions between the fiscal and the philosophical, between changing fortunes and changing attitudes. The dichotomy is not absolute, of course. Even as many are rethinking criminal justice responses, particularly for nonviolent, substanceabusing offenders, there are others preserving resources until they can again afford the largely punitive responses of previous decades. There are also those whose views fall in between or are in flux. On balance, what do these recent state responses portend? Are advocates of indiscriminate tough-on-crime policies simply waiting out the lean times? Or have the budget crises helped to cultivate a sustainable appetite for new approaches to sentencing and incarceration?

The actions reported in this paper, particularly the case studies discussed in the second half, indicate that while the budget crises are providing the occasion for change, the reforms are often anchored in changing attitudes and philosophy. These are evident in a greater use of data to structure sentencing, a reliance on proportionality in determining appropriate sentences, and a renewed focus on rehabilitiation. The mass of activity in the 2003 legislative sessions suggests that many policymakers have become emboldened to change the way states approach sentencing and corrections. If this is indeed the case, we may well see the emerging correctional reforms outlast the budget crises. 


\section{Endnotes}

1 For a discussion of states' first responses to their budget crises, see Daniel F. Wilhelm and Nicholas R. Turner, "Is the Budget Crisis Changing the Way We Look at Sentencing and Incarceration?" Issues in Brief (New York: Vera Institute of Justice, June 2002). For a survey of trends of the past few years, see Judith A. Greene, Positive Trends in State-Level Sentencing and Corrections Policy (Washington, DC: Families Against Mandatory Minimums, November 2003). See also Fox Butterfield, "With Cash Tight, States Reassess Long Jail Terms," New York Times, 10 November 2003, p. 1 <http://www.nytimes.com/2003/11/10/national/10PRIS.html> (accessed 10 November 2003); Paul von Zielbauer, "Rethinking the Key Thrown Away," New York Times, 28 September 2003, p. 41 <http://www.nytimes.com/2003/09/28/nyregion/28SENT.html> (accessed 29 September 2003).

2 State Budget Update: April 2003 (Washington, DC: National Conference of State Legislatures, April 2003). Also see The Fiscal Survey of States (Washington, DC: National Governors Association and National Association of State Budget Officers, June 2003).

3 See "Fiscal Storm Shows Signs of Subsiding," NCSL News, 21 November 2003, <http://www.ncsl.org/programs/press/2003/ pr031121.htm > (accessed 28 November 2003) which indicates that fewer states were reporting budget gaps and roughly half the states saw revenues as stable; Jason White, "State fiscal picture brightening," 13 November 2003, <http//www.stateline.org> (accessed 14 November 2003), which suggests that a few states are beginning to report modest revenue growth such that midyear cutbacks may not be required. However, 30 states' projected deficits for fiscal year 2005 total $\$ 39$ to $\$ 41$ billion. Nicholas Johnson and Bob Zahradnik, State Budget Deficits Projected for Fiscal Year 2005, Center on Budget and Policy Priorities, rev. 6 February 2004, <http://www.cbpp.org/10-22-03sfp2.pdf> (accessed 18 February 2004).

4 Between 1995 and 2002, states' populations of sentenced prisoners increased by 236,000, an increase of 24 percent. Paige M. Harrison and Allen J Beck, Prisoners in 2002 (Washington, DC: U.S. Department of Justice, Bureau of Justice Statistics, July 2003), Table 4.

5 Vera conducted two companion inquiries. We obtained corrections budget and administrative cost-cutting information from executive budget officers in every state through e-mail and telephone inquiries, and we gathered legislative information from periodic searches of electronic legal databases. In many cases we followed up by telephoning legislators, judges, and executive branch officials to gain a fuller understanding of the deliberative processes underlying administrative and legislative changes. Only 34 states provided actual expenditure figures for 2002 and 2003; 48 states provided initial appropriations figures for 2003 and 2004. Ten of 46 states providing data showed declines in initial appropriations figures for 2003. Examinations of these figures relying on different methodologies produce somewhat different results. For example, the National Conference of State Legislatures reports that "[e]leven of 49 states have actual reductions in corrections dollars from FY 03 to FY 04." State Budget Actions 2003, (Washington, DC: National Conference of State Legislatures, forthcoming).

6 Fox Butterfield, "States Putting Inmates on Diets to Trim Budgets," New York Times, 30 September 2003, p. 18 <http://www.nytimes.com/ 2003/09/30/national/30PRIS.html> (accessed 30 September 2003).

7 For a discussion of the history and appropriateness of offender fees, see John Howard Society of Alberta, Correctional User Fees, 2001.

8 "Community Supervision Legislative Overview," Texas SuperVision: A Professional Journal for Community Supervision in Texas (October 2002), 1-4

9 "Getting inmates to pay jail costs proves difficult, counties find," Star Tribune, 15 September 2003, <http://www.startribune.com/viewers/story.php?template $=$ print a\&story $=4098016>$ (accessed 17 September 2003).

10 Michael Tonry, "Sentencing Commissions and Their Guidelines," Crime and Justice 17 (1993), 137-38.

11 Ibid.

12 A number of states considered but did not enact legislation increasing early release credits or otherwise expediting eligibility for release. Among these are California, Kentucky, Maryland, and Oregon. Additionally, in Colorado, Governor Bill Owens vetoed a bill that would have increased earned time credits from 10 to 12 days per month for nonviolent offenders who previously had not served a state sentence.

13 Readers should bear in mind that some of those committed without a new conviction had pending criminal charges that were dropped because it was expected they would return to prison on the violation.

14 Paige M. Harrison and Jennifer C. Karberg, Prison and Jail Inmates at Midyear 2002 (Washington, DC: U.S. Department of Justice, Bureau of Justice Statistics, 2003). National statistics do not provide probation violation numbers and do not expressly differentiate between technical and non-technical violators.

15 Kansas Sentencing Commission, Fiscal Year 2004 Adult Inmate Prison Population Projections (September 2003), 10.

16 Lauren E. Glaze, Probation and Parole in the United States, 2002 (Washington, DC: U.S. Department of Justice, Bureau of Justice Statistics, August 2003).

17 Sentencing Accountability Commission of Delaware, Sentencing Trends and Correctional Treatment in Delaware (April, 2002).

18 In 2001, 1,798 Colorado parolees were revoked to prison for technical violations. This represents 31 percent of the state's parole caseload and 21 percent of prison admissions. Michael Jacobson, National Trends in Adult Parole Populations, presentation to the Little Hoover Commission, public hearing on parole reform, January 23, 2003.

19 In 2000, Michigan had the highest average drug sentence in the nation, 182 months compared with a national average of 66 months. National Corrections Reporting Program, 2000, <http://www.icpsr.umich.edu:8080/NACJD-STUDY/03761.xml> (accessed 17 December 2003).

20 Anthony Brown, Delegate, Maryland House of Delegates. All statements attributed to Delegate Brown are based on phone interview with authors, 2 February 2004.

21 Chad Kinsella and Karen Fuller, "Community-based supervision dilemma: Corrections programs targeted for cuts as prison populations rise," State Government News (May 2003), 16. 


\section{Issues in Brief}

22 Lori Montgomery, "Md. Prisons to Focus on Rehabilitation," Washington Post, 6 November 2003, B1.

23 A number of other states — Louisiana, Massachusetts, Montana, and North Carolina, among them—considered but did not enact diversion to treatment bills in the 2003 session.

24 See, for example, Peter D. Hart Research Associates, Inc., The New Politics of Criminal Justice: Summary of Findings, January 2002. The results of this public opinion poll suggest a shift toward favoring prevention and other approaches to the causes of crime and away from punishment, especially for non-violent offenders.

25 Alabama incarcerates 610 persons per 100,000 residents; the national average is 427. Paige M. Harrison and Allen J. Beck, Prisoners in 2002 (Washington, DC: U.S. Department of Justice, Bureau of Justice Statistics, July 2003), Table 4.

26 Lynda Flynt, Executive Director, Alabama Sentencing Commission. All statements attributed to Ms. Flynt are based on phone interview with authors, 5 December 2003.

27 Alabama Sentencing Commission, Recommendations for Reform of Alabama's Criminal Justice System: 2003 Report: "A Rational Approach to Sentence Reform," (March 2003)

28 Rosa Davis, Chief Assistant Attorney General, commission member and executive committee member, Alabama Sentencing Commission. All statements attributed to Ms. Davis are based on phone interview with authors, 5 December 2003.

29 Notable exceptions are Michigan, which significantly reduced mandatory minimum sentences for most drug offenses, including sale and possession with intent to sell, and Washington, which in 2003 accelerated implementation of a new drug sentencing grid enacted in 2002

30 Richard Gebelein, Superior Court Judge, New Castle County; former Chairman of Delaware's Sentencing Accountability Commission. Al statements attributed to Judge Gebelein are based on phone interview with authors, 18 November 2003

31 Steven Wood, Deputy Attorney General. All statements attributed to Mr. Wood are based on phone interview with authors, 26 November 2003.

32 Victor Battaglia, Sr., Secretary/Treasurer, Stand Up for What is Right and Just. All statements attributed to Mr. Battaglia are based on phone interview with authors, 21 November 2003.

33 Barbara Tombs, former Executive Director, Kansas Sentencing Commission. Ms. Tombs is currently Executive Director of the Minnesota Sentencing Guidelines Commission. All statements attributed to Ms. Tombs are based on phone interview with authors, 20 November 2003.

34 Senator John Vratil, Kansas State Senate, e-mail correspondence with authors, 27 October 2003.

35 In 2002, Arizona incarcerated 29,103 offenders, a rate of 508 per 100,000 in the population. The 13 western states and national average rates of incarceration are 413 and 425 per 100,000, respectively. Arizona's prison population grew by 7.2 percent; the average among all states was 0.9 percent. Paige M. Harrison and Jennifer C. Karberg, Prison and Jail Inmates at Midyear 2002 (Washington, DC: U.S. Department of Justice, Bureau of Justice Statistics, 2003).

36 In recognition of the importance of investing in supportive services prior to and after offenders' release from prison, the federal Serious and Violent Offender Reentry Initiative, created in 2002, provides roughly $\$ 2$ million to each state over two years to support new or expanded reentry programs.

37 Senator Mark Anderson, Arizona State Senate. All statements attributed to Senator Anderson are based on phone interview with authors, 20 November 2003

\section{altus ${ }^{\oplus}$}

Vera is a founding member of Altus (c) Vera Institute of Justice 2004. All rights reserved.

This project was supported by the U.S. Department of Justice, Office of Justice Programs, National Institute of Justice. Points of view or opinions contained in this document are those of the authors and do not necessarily represent the official position or policies of the U.S. Department of Justice.

This report would not have been possible without the work of Emma Freudenberger of the Vera Institute and student interns Kathleen Liu of Princeton University and Leah Cover of the University of Chicago Law School, who spent many hours tracking bills and corrections data throughout the 50 states.

Additional copies are available from the State Sentencing and Corrections Program at the Vera Institute of Justice, 233 Broadway, 12th Floor, New York, New York, 10279, (212) 334-1300. An electronic version is posted on Vera's web site, www.vera.org.

The Vera Institute of Justice is a private, nonprofit organization dedicated to making government policies and practices fairer, more humane, and more efficient. Working in collaboration with public officials and communities in the United States and throughout the world, Vera designs and implements innovative programs that expand the provision of justice and improve the quality of life.

The State Sentencing and Corrections Program (SSC) is one of several national consulting and technical initiatives Vera operates. The program helps government officials develop balanced, fair, and affordable criminal justice policies by providing peer-to-peer assistance. To learn about how SSC can be of assistance, call (212) 376-3073, write to dwilhelm@vera.org, or visit the program's web site at www.vera.org/ssc. 